\title{
CHAPTER 32 \\ Sustainable Development Goals and Health: Toward a Revolution in Values
}

\author{
Jeffrey D. Sachs
}

\begin{abstract}
All of this shows the urgent need for us to move forward in a bold cultural revolution. Science and technology are not neutral; from the beginning to the end of a process, various intentions and possibilities are in play and can take on distinct shapes. Nobody is suggesting a return to the Stone Age, but we do need to slow down and look at reality in a different way, to appropriate the positive and sustainable progress which has been made, but also to recover the values and the great goals swept away by our unrestrained delusions of grandeur.
\end{abstract}

Pope Francis, Laudato Si', 114

Pope Francis calls for a revolution in governance, to manage technologies for the common good. In my mind, this brings us back to politics in the tradition of Aristotle rather than the tradition of Machiavelli. For Aristotle, politics is about wellbeing (eudaimonia) of the polis, the political community. For Machiavelli, politics is about the struggle for power, little more. It should be clear that we are today living in Machiavelli's political world, not in Aristotle's.

To return to Aristotle's politics, we need a shared conception of the common good based on human nature. It seems to me that our great moral traditions, and in particular the Church's social teachings, offer us deep guidance. We should give priority to the poor; defend human dignity; promote the cardinal virtues of justice, fortitude, prudence, and practical wisdom; and dismantle the structures of sin, including pervasive corporate cheating, corporate lobbying, corporate campaign financing, and tax havens that facilitate global corporate and personal tax evasion of the rich on an unfathomable scale.

The 17 Sustainable Development Goals (SDGs), shown in Fig. 32.1, were adopted by all 193 UN member states in September 2015 to cover the period 2016-2030. The SDGs provide the best opportunity for a new cooperative global politics oriented around the common good. The SDGs aim for economies that are prosperous, socially inclusive, and environmentally sustainable. In the jargon of the

\footnotetext{
J. D. Sachs $(\bowtie)$

Columbia University and Director of the UN Sustainable Development Solutions Network, Columbia University, New York, NY, USA

e-mail: sachs@columbia.edu
} 


\section{1 mover Minition}
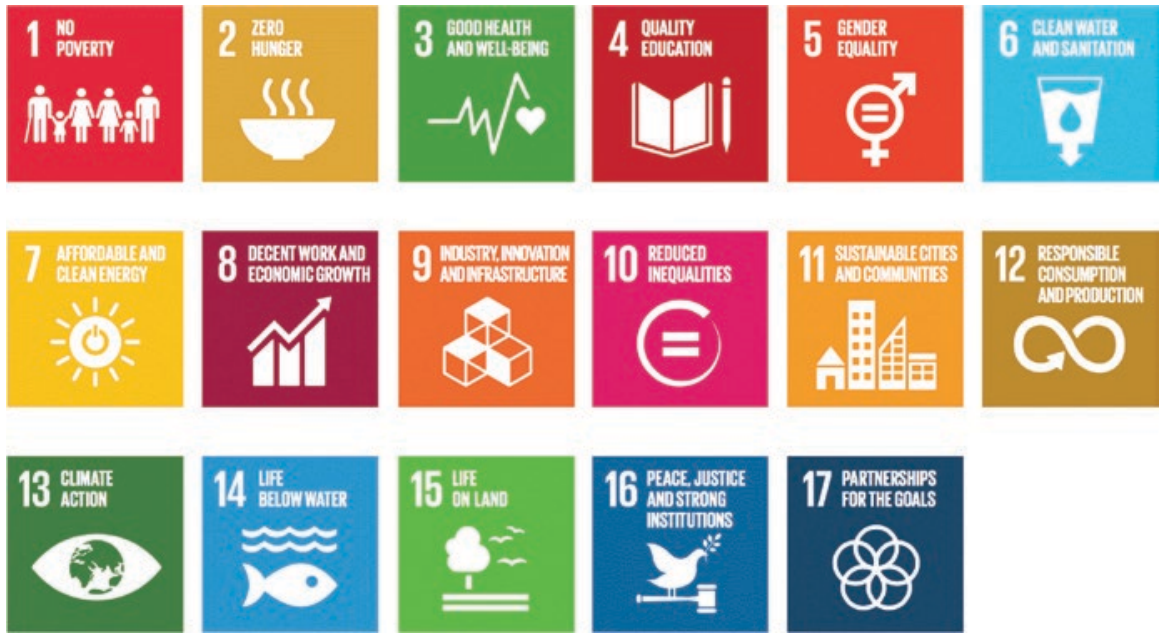

Fig. 32.1 The 17 sustainable development goals

UN, the SDGs should "leave no one behind," including future generations and indeed other species and Earth itself.

There are two intersecting themes to consider. The first theme is that we must move to a clean energy system, one that stops the emission of greenhouse gases and cleans the air for human health. The energy goals are covered by SDGs 7 and 13. The goals on human health are covered by SDG 3 (healthy lives for all at all ages).

The second theme is that we must move to a sustainable food system, one that promotes healthy diets for all while eliminating the massive environmental destruction caused by current farming practices. These food-sector objectives are covered especially by SDG 2 (sustainable agriculture), SDG 14 (sustainable marine ecosystems), and SDG 15 (sustainable terrestrial ecosystems). Again, one priority is that healthy diets reduce disease and premature mortality, especially by combatting the worldwide obesity and metabolic disease epidemics caused by "fast food." Both for energy and food, the biggest challenge we face is the structures of sin, namely, the power of corporate food and agricultural giants whose greed and irresponsibility undermine the common good.

When it comes to energy, the challenge is rather easily expressed. The world should decarbonize the global energy system by 2050 in order to achieve the Paris Climate Agreement goal of keeping global warming below $1.5^{\circ} \mathrm{C}$. This means, at the core, a shift from fossil fuels (coal, oil, and natural gas) to renewable energy, especially wind, solar, hydro, and geothermal energy. This shift is feasible and even economical if carried out rigorously and expeditiously over the period to 2050 .

In a nutshell, all electricity should be produced by zero-carbon energy. All transport should be electrified (as with light-duty vehicles) or should transition to using synthetic fuels produced by zero-carbon electricity. Such fuels include hydrogen and synthetic liquid hydrocarbons. All buildings should be electrified for heating and cooking. All heavy industry should find alternatives to carbon emissions. Technological solutions exist or are within reach in each case. 
These energy shifts will have two benefits: saving the climate and cleaning the air. Zero-carbon energy sources will reduce PM2.5 aerosols and other environmental pollutants, and the co-benefits of health are an enormously important reason to accelerate the shift to clean energy. India, for example, currently loses more than a year of life expectancy from massive air pollution, and in some states, more than 2 years of life expectancy.

Despite the urgent need for rapid decarbonization of energy, the process continues to be blocked by the corporate greed of companies such as ExxonMobil, Chevron, Gazprom, BHP, and the like. These companies will cause massive detriment to populations vulnerable to air pollution unless they are decisively brought under regulation, yet in the United States, Australia, Canada, Russia, and other countries, the oil industry rather than the common good directs politics. We are in the political world of Machiavelli rather than Aristotle.

The same tendency is clear in the food sector. Current global agricultural practices are wholly inadequate, indeed in crisis, for three reasons. First, the agricultural sector is a huge contributor to environmental catastrophe: deforestation, eutrophication, chemical pollutants, massive greenhouse gas emissions, invasive species, and others. Second, the agriculture sector is undermining its own long-term viability by destroying the land and soil and increasing its own vulnerability to climate change. Third, the diet produced by today's food industry is disastrous, especially through the spread of obesity and food addictions caused by sugar additives, saturated fats, and heavy food processing.

Once again, the solutions are rather easily described. We need to move from heavy beef consumption to diets that are based far more on plant proteins, notably nuts, legumes, and fruits. We need to enforce strong land-use regulations that protect biodiversity and stop the conversion of forests and grasslands into new pasturelands for beef.

As with energy, these changes are scientifically sound, morally correct, and technologically feasible, yet they are being stalled or slowed by the likes of Coca Cola, PepsiCo, McDonald's, Kentucky Fried Chicken, Kraft Heinz, and other food giants. These companies are massive lobbyists and major campaign contributors in the United States. They are part of the structures of sin, since they carry on with their destructive products even when the evidence is overwhelming that they are the creators of the global obesity epidemic and much else that is wrong with the world's diets.

What, then, will be the path of the bold cultural revolution called for by Pope Francis? It will have the following steps:

1. Putting the common good and human dignity in the highest purpose of politics;

2. Choosing the preferential option for the poor;

3. Adopting the SDGs and the Paris Climate Agreement as guiding principles for the world's governments and businesses;

4. Preparing plans to achieve the SDGs and the Paris Climate Agreement based on the best scientific information and in processes marked by transparency, justice, and public inclusion;

5. Adopting SDG and climate indicators to ensure accountability of governments and businesses;

6. Dismantling the structures of sin that have placed corporate greed above the common good. 
Open Access This chapter is licensed under the terms of the Creative Commons Attribution 4.0 International License (http://creativecommons.org/licenses/by/4.0/), which permits use, sharing, adaptation, distribution and reproduction in any medium or format, as long as you give appropriate credit to the original author(s) and the source, provide a link to the Creative Commons license and indicate if changes were made.

The images or other third party material in this chapter are included in the chapter's Creative Commons license, unless indicated otherwise in a credit line to the material. If material is not included in the chapter's Creative Commons license and your intended use is not permitted by statutory regulation or exceeds the permitted use, you will need to obtain permission directly from the copyright holder. 